\title{
42. 生命の水・信濃川源流
}

\section{WATER OF LIFE • SOURCE OF SHINANO RIVER}

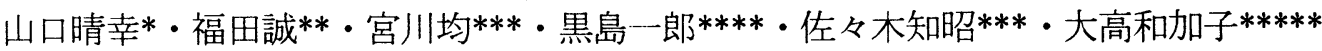

\begin{abstract}
Hareyuki YAMAGUCHI· Makoto FUKUDA · Hitoshi MIYAKAWA · Ichirou KUROSHIMA · Tomoaki SASAKI • Wakako OHTAKA
\end{abstract}

ABSTRACT: The natural environmental investigations were carried out on the source of Shinano river and its basin. At the beginning, the method of natural environmental investigation was simply represented. In this report, in particular, the authors clarifly the ture character of source of Shinano river. Moreover, the data of chemical analysis about water qualities of source zone of Shinano river and natural water in its basin and Kanto area are shown, and the real condition of water environment in the water system of Shinano river is discussed.

KEYWARD: Source of Shinano river, Water system, Water environment, Water quality, Natural water

\section{1. 序にかえて}

近年、地球規模の環境污染や身近な自然環境の破壊・消滅など、さまざまな自然環境問題が発生し、国 際的、社会的に重要な問題となっています。これからの地域環境と開発・建設問題や自然環境の保護・保全 活動の有り方などの一助として役立てることを目的として、広域的な自然環境調査を継続しています。特に、 著者らは、自然の恵み「生命の水」を育む自然環境保全の貴重性と重要性に警鐘を鳴らすために、我が国に おける主要な河川とその流域等を対象として、源流から河口まで広範囲に亘る水・土・植生・水生生物環境 に関する調査を実施しています。既に、多摩川源流と利根川源流の正体や源流加ら河口に至る水質の推移及 び流域一体の自然水の水環境の実態等について報告してきました。本報告では、信濃川の源流とその周辺及 び流域を対象に継続している自然環境調査での、水環境に関する成果の一部を提示し、悪化する自然環境の 保全と回復の重要性について考察しています。

\section{2. 調査と目的}

著者らの調查方法と目的としては、我が国に抢ける代表的な大河川を対象として、主に、(1)源流地点の 確認と源流となる自然水の環境、(2源流から河口に至る本流の自然水の環境とその変化状況、(3)本流に流 人する主要支川の合流点における自然水の環境、(4)水系一帯での主要・著名な湧水や地下水等の自然水の 環境、(5)水系に繁茂する巨樹（樹齢 500 年以上対象）と水環境、(6)水系に生息する希少水生生物と水環境、 (7)水と土環境の事項から、広域的にしかも複合的に自然環境の実態を明らかにし、自然環境の保護・保全 活動の有り方などについて提示することにあります。ここでは、成果の一部として、信濃川源流の正体と源

* 防衛大学校 土木工学教室

** 国立長岡工業高等専門学校 都市環境工学科

*** 防衛施設庁 本庁

$* * * *$ 三井建設㑣

$* * * * *$ 内藤環境管理㑣 環境技術研究所 
流域周辺の水質特性及びその流域を含めた関東一円に点在寸る著名な名水之呼ばれる自然水の水質特性につ いて記述します。

\section{3. 信濃川源流と流域の概説}

周知にように、信濃川は河川長 $367 \mathrm{~km}$ 有する我が国最長の河川である。流域は長野県・新潟県にまたが り、11900 $\mathrm{km}{ }^{2}$ の流域面積は第 3 位であるが、年間の流れる水の量は、15304 百万 $\mathrm{m}^{3}$ に及ぶと言われ、我が 国最大の流量を誇る河川である（図-1）。ちなみに、「関東の水がめ」利根川の年間に流れ出る水の量は 9313 百万 $\mathrm{m}^{3}$ (第 5 位) に比較して、約 1.6 倍に達している。信濃川は甲武信岳（標高 $2475 \mathrm{~m}$ 、長野県）の山頂 付近（標高約 $2210 \mathrm{~m} ） に$ 源を発している。この河川本流は長野県を流れる流域では「千曲川」、新潟県の中、 下流域では「信濃川」と呼ばれている。越後の国（新潟県）を流れているのに「信濃川」と呼ばれているの には、信濃の国 (長野県) の方から流れてくる川という意味であるためと言われている。歴史的利水・治水 の背景から、信濃川には多くの巨大な堰が建造されている。特に新潟市街で日本海に出る下流域には、土木 工学的遺産としても非常に貴重な大河津分水や関谷分水路などが建造されており、河川工学的にも重要な役 割を果たしている。

\section{4. 源流域の正体と源流域の水環境}

著者らは、平成 9 年 9 月 28 日信濃川（千曲川）源流への道をたどり、源流の正体を確認し、源流及び源 流域一帯の水環境調査を実施した。甲武信岳山頂付近にある源流（標高約 $2210 \mathrm{~m} ）$ の正体怄、一帯の花こ う岩の地層から湧水する清洌な伏流水であった（写真-1）。表-1 に源流及び源流域等で現地計測した自然水 の $\mathrm{pH}$ 、電気伝導率 $(\mathrm{EC}) 、$ 水温 $(\mathrm{T})$ と、主要な溶存イオン成分をまとめている。また同表には、期日は異

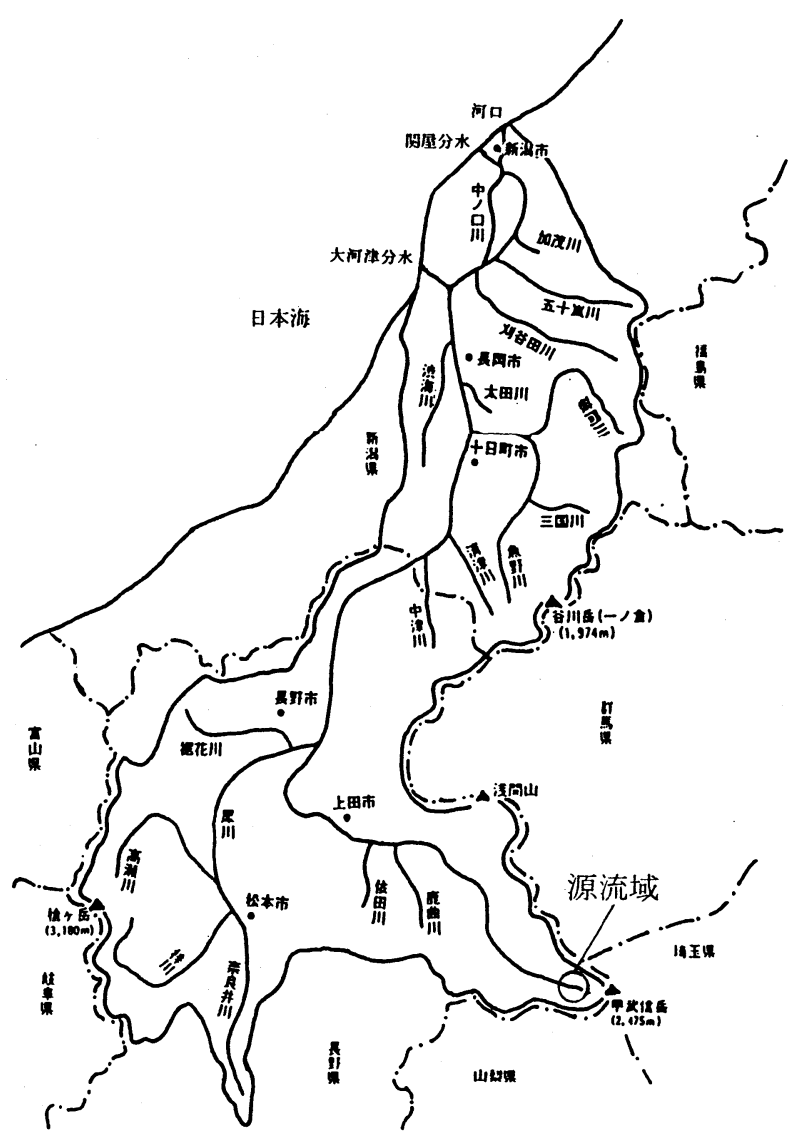

図-1 信濃川（千曲川）源流とその流域源流域

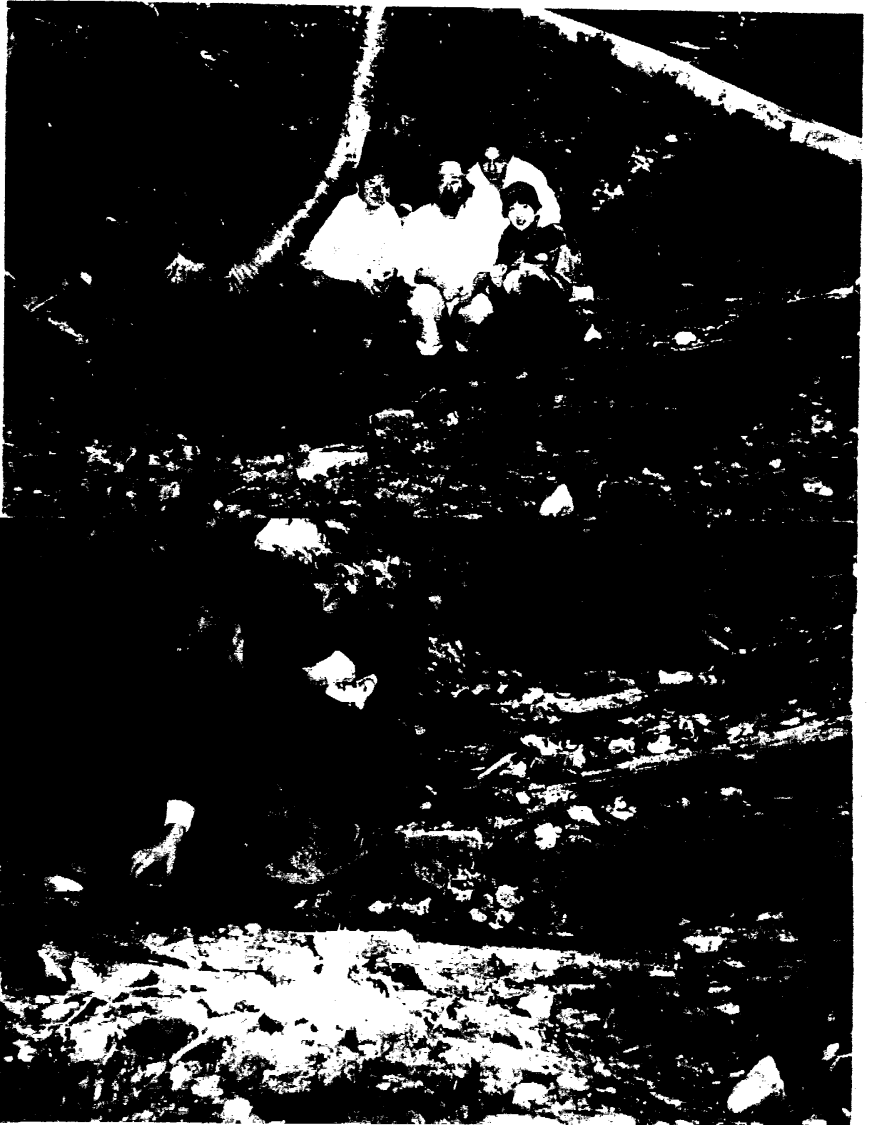

写真-1 信濃川（千曲川）源流の正体は伏流水 
表-1 信濃川（千曲川）源流及び流域の水質分析結果

\begin{tabular}{|c|c|c|c|c|c|c|c|c|c|c|c|c|c|c|c|c|c|}
\hline \multirow[t]{2}{*}{$\mathrm{Na}$} & \multirow[t]{2}{*}{ 採取年月日 } & \multirow[t]{2}{*}{ 場所 } & \multirow[t]{2}{*}{ 標高 } & \multirow{2}{*}{ 永形態 } & \multirow{2}{*}{$\mathrm{pH}$} & \multirow{2}{*}{$\begin{array}{c}E C \\
(\mu \mathrm{s} / \mathrm{cm})\end{array}$} & \multirow{2}{*}{$\begin{array}{c}\mathrm{T} \\
\left({ }^{\circ} \mathrm{C}\right)\end{array}$} & \multicolumn{4}{|c|}{ 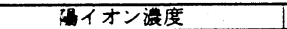 } & \multicolumn{4}{|c|}{ 陰イオン眼度 } & \multirow{2}{*}{$\begin{array}{l}\text { 全硬度 } \\
(\mathrm{mg} / 1)\end{array}$} & \multirow{2}{*}{$\begin{array}{c}\text { 全イオン灤闵 } \\
(\mathrm{mg} / 1)\end{array}$} \\
\hline & & & & & & & & Ya & $\begin{array}{ll}k \\
k\end{array}$ & $\mathrm{Ca}$ & $\mathrm{Mg}$ & $\mathrm{HCO} 3$ & $\mathrm{Cl}$ & NO3 & S04 & & \\
\hline 1 & H.9.9.28. & 源流 & 2,210 & 盙水 & 6.8 & 23 & 3.71 & 1.5 & 0.8 & 2.5 & 0.2 & 8.8 & 0.5 & 1.1 & 2.5 & 7.1 & \\
\hline 2 & H. 9.9.28. & 源流 & 2,210 & 涌水 & 6.7 & 22 & 3.7 & 1.2 & 0.8 & 2.4 & 0.3 & 8.4 & 0.5 & 0.8 & 2.4 & 7.1 & 16.70 \\
\hline 3 & H. 9.9.28. & 源流 & 2,210 & 涌水 & 6.7 & 22 & 3.8 & 1.3 & 0.9 & 2.5 & 0.3 & 8.9 & 0.6 & 0.9 & 2.4 & 7.4 & 17.84 \\
\hline 4 & H.9.9.28. & 源流域 & 2,130 & 澡流水 & 7.4 & 28 & 4.2 & 1.4 & 0.8 & 2.8 & 0.4 & 9.8 & 0.5 & 0.4 & 3.3 & 8.6 & 19.33 \\
\hline 5 & H. 9.9. 28. & 源流域 & 2,080 & 渓流水 & 7.4 & 26 & 5.0 & 2.1 & 1.1 & 2.7 & 0.4 & 9.1 & 0.5 & 0.5 & 5.4 & 8.3 & 21.79 \\
\hline 6 & H.9.9.28. & 源流域 & 2,000 & 溪流水 & 7.2 & 29 & 5.5 & 1.4 & 0.4 & 2.8 & 0.4 & 6.7 & 0.4 & 0.4 & 5.6 & 8.5 & 18.02 \\
\hline 7 & H. 9.9.28. & 源流域 (十又滰) & 1,920 & 渎流水 & 7.6 & 40 & 6.1 & 1.8 & 0.4 & 4.2 & 0.4 & 6.8 & 0.6 & 0.4 & 9.3 & 12.1 & 23.87 \\
\hline 8 & H. 9.9.28. & 源流域 & 1,845 & 溪流水 & 7.2 & 84 & 5.6 & 2.1 & 0.7 & 11.3 & 0.6 & 19.0 & 0.9 & - & 18.6 & 30.7 & 53.19 \\
\hline 9 & H. 9.9.28. & 源流域 & 1,820 & 溪流水 & 7.4 & 35 & 5.8 & 1.5 & 0.7 & 3.8 & 0.6 & 13.4 & 0.4 & - & 4.4 & 12.1 & 24.83 \\
\hline 10 & H. 9.9.28. & 源流域 & 1,810 & 溪流水 & 7.3 & 90 & 6.5 & 2.1 & 0.7 & 12.7 & 0.5 & 12.5 & 0.6 & - & 26.9 & 33.8 & 55.89 \\
\hline 11 & H. 9.9.28. & 獂流域 & 1,810 & 渓流水 & 7.3 & 43 & 6.0 & 1.8 & 0.4 & 4.8 & 0.4 & 6.9 & 0.5 & 0.4 & 10.9 & 13.6 & 25.97 \\
\hline 12 & H. 9.9.28. & 源流域 & 1,735 & 溪流水 & 7.4 & 47 & 6.2 & 1.8 & 0.5 & 5.5 & 0.4 & 6.9 & 0.5 & 0.3 & 12.9 & 15.6 & 28.70 \\
\hline 13 & H. 9.9.28. & 源流域 & 1,605 & 溪流水 & 7.6 & 29 & $7: 2$ & 1.6 & 1.0 & 2.7 & 0.5 & 11.0 & 0.4 & - & 3.5 & 8.5 & 20.68 \\
\hline 14 & H.9.9.28. & 源流域 & 1,600 & 溪流水 & 7.3 & 27 & 7.4 & 1.2 & 0.3 & 2.8 & 0.4 & 9.1 & 0.5 & 0.4 & 3.1 & 8.7 & 17.76 \\
\hline 15 & H. 9.9.28. & 源流域 & 1,585 & 溪流水 & 7.6 & 46 & 7.0 & 1.7 & 0.5 & 5.4 & 0.5 & 7.0 & 0.5 & 0.3 & 12.5 & 15.3 & 28.38 \\
\hline 16 & H. 9.9.28. & 源流域 & 1,545 & 溪流水 & 7.6 & 43 & 7.2 & 1.6 & 0.4 & 5.2 & 0.4 & 7.7 & 0.5 & 0.5 & 10.8 & 14.7 & 27.10 \\
\hline 17 & H. 9.9.28. & 源流域 & 1,520 & 溪流水 & 7.8 & 43 & 7.2 & 1.6 & 0.4 & 5.3 & 0.4 & 8.1 & 0.6 & 0.5 & 10.7 & 14.9 & 27.63 \\
\hline 18 & H. 9.9.28. & 源流域 & 1,485 & 慀流水 & 7.7 & 43 & 7.2 & 1.7 & 0.5 & 5.1 & 0.4 & 7.7 & 0.6 & 0.5 & 10.6 & 14.4 & 27.09 \\
\hline 19 & H. 9.9.28. & 上流城 & 1,310 & 滛流水 & 7.7 & 54 & 8.0 & 1.8 & 0.5 & 6.8 & 0.7 & 17.2 & 0.8 & 0.3 & 8.6 & 19.9 & 36.63 \\
\hline 20 & H. 9.9.28. & 上流城 & 1,325 & 溪流水 & 8.4 & 36 & 9.0 & 1.6 & 0.7 & 4.0 & 0.6 & 13.7 & 0.6 & 0.2 & 4.0 & 12.2 & 25.31 \\
\hline 21 & H. 9.9.28. & 上流域 & 1,220 & 港流水 & 7.3 & 42 & 12.2 & 2.5 & 0.5 & 4.3 & 0.5 & 13.5 & 1.7 & 1.5 & 4.1 & 12.9 & 28.59 \\
\hline 22 & H. 9.9.28. & 上流城 & 1,120 & 溪流水 & 7.3 & 78 & 12.5 & 3.4 & 1.0 & 8.7 & 1.7 & 25.4 & 2.6 & 8.5 & 5.5 & 28.4 & 56.62 \\
\hline 23 & H.9.4.1. & 長野県上田体 & 420 & 河川水 & 7.7 & 157 & 12.0 & 10.6 & 1.9 & 13.3 & 4.2 & 43.9 & 12.3 & 4.7 & 17.8 & 50.1 & 108.65 \\
\hline 24 & H. 9.10 .6 . & 新㳦果長岡甫 & 10 & 河川水 & 7.5 & 155 & 17.5 & 11.1 & 2.0 & 13.7 & 3.3 & 38.0 & 12.8 & 4.4 & 20.6 & 47.5 & 105.81 \\
\hline 25 & H.9.10.6. & 新泻県新潟本 & 3 & 河川水 & 6.8 & 240 & 18.2 & 24.3 & 4.9 & 12.8 & 4.2 & 37.8 & 38.3 & 6.1 & 17.8 & 49.1 & 146.01 \\
\hline 26 & H. 9.10.7. & 新捣紧新渴甫 & 2 & 河川水 & 7.0 & 193 & 18.2 & 18.2 & 3.1 & 11.6 & 3.7 & 34.0 & 25.8 & 5.1 & 18.5 & 44.0 & 119.98 \\
\hline
\end{tabular}

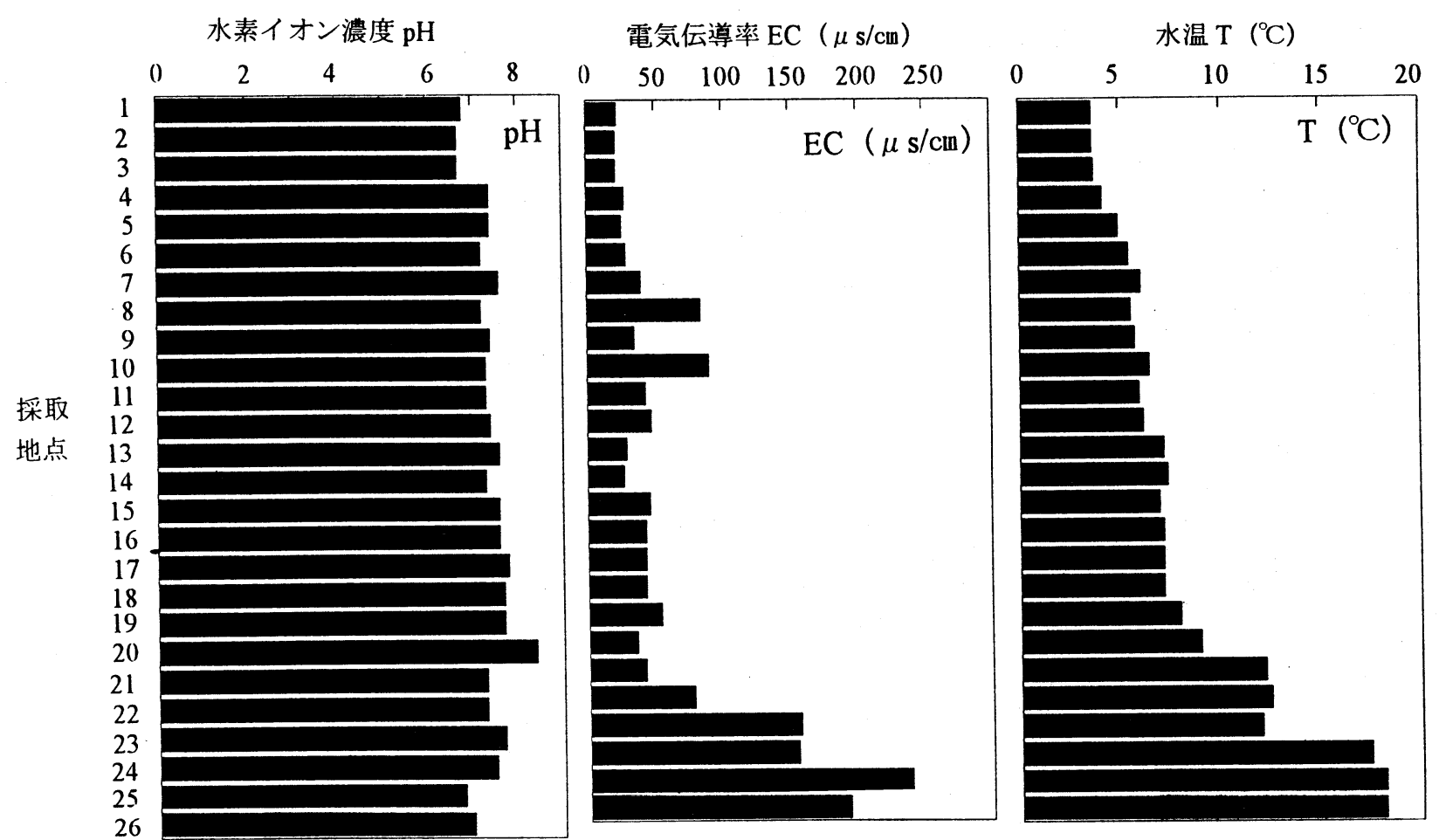

図-2 信濃川（千曲川）での pH、EC、Tの源流から河口までの推移

なるが中流域及び下流域（No.23 26）で計測・分析した值も併記している。提示した表-1 に基づき、千曲 川・信濃川の源流から河口までの代表的な水質特性を図式化したのが図-2 4 である。源流（No.13）、源流 域（No.4 18）、上流域（No.19 22）の標高 $1100 \mathrm{~m}$ 以上の甲武信岳付近の自然水は、EC がほとんど $50 \mu \mathrm{s} / \mathrm{cm}$ 以下で、極めて溶存イオン量の低いことが分かる。特に源流の伏流水（No.1 3） は、pH が 6 台の弱酸性で、

$\mathrm{EC}$ も $20 \mu \mathrm{s} / \mathrm{cm}$ 台で $3^{\circ} \mathrm{C}$ 台の水温（外気温 $0^{\circ} \mathrm{C}$ ) であった。図-3 でのへキサダイヤグラムからも、これらの 自然水の各イオン成分の濃度は極めて低く、図-4 でのトリリニアダイヤグラム上では、水質タイプとして 

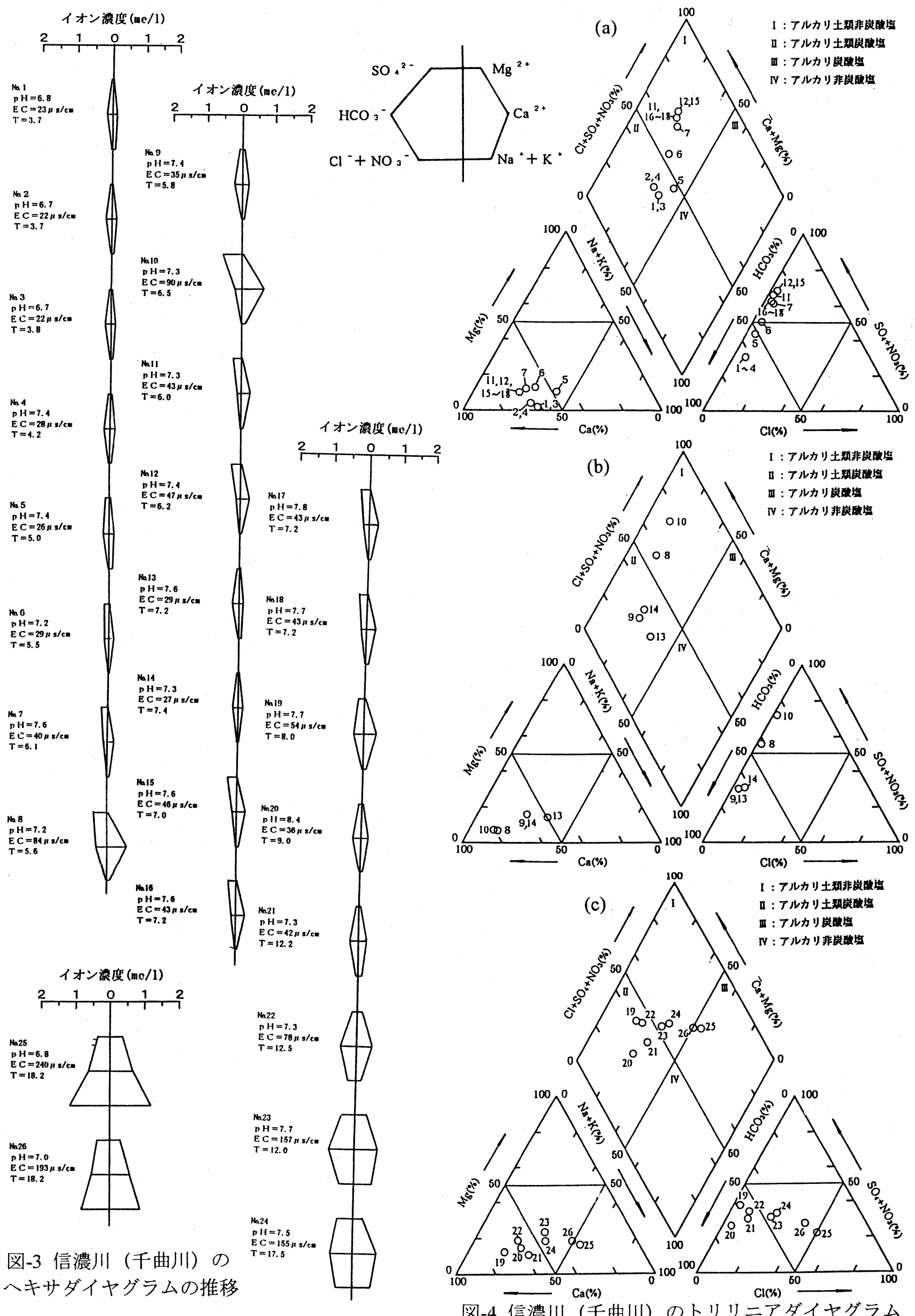

図-4 信濃川（千曲川）のトリリニアダイヤグラム 
アルカリ土類炭酸塩（源流域など）とアルカリ土類非炭酸塩に分類されることがわかる。また中流域や下流 域（No.23 26）の水質も、367 kmの河川長から考える上、その水質変化が比較的小さいことが、特徴的であ ると言える。
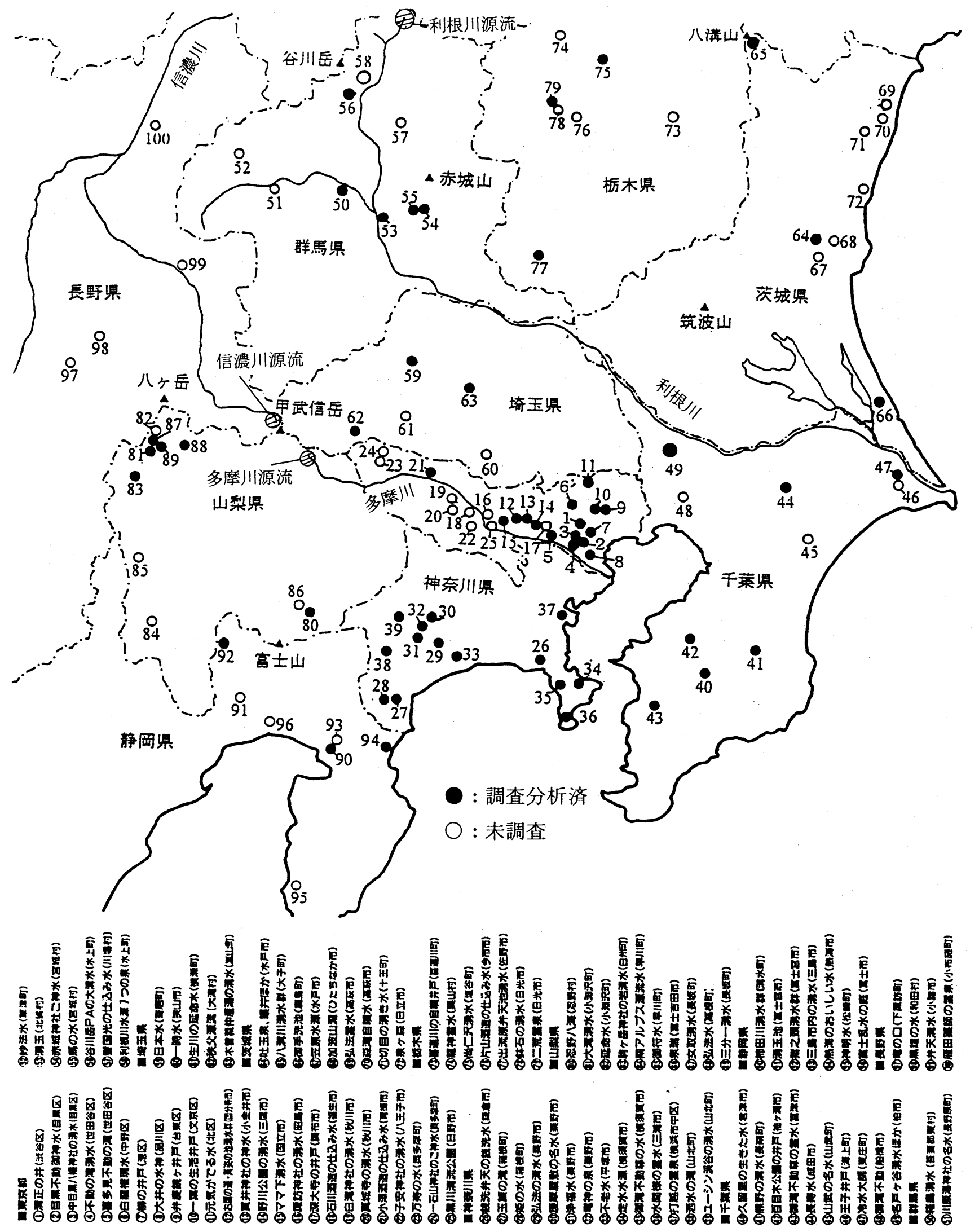

図-5 調査対象とした関東域に散在する自然水 100 箇所 
5. 関東域に散在する主要な自然水の水質特性

著者らは、既でに、関東地方の主要な河川である多摩川と利根川を対象に、その源流の正体と源流域の 水質特性や両流域に点在する主要な名水と呼ばれている自然水の水質タイプ等について報告してきた（図5)。これらの名水と呼ばれる自然水も含め、関東域に散在する 100 箇所の名水を選定し、これらの自然水の 水質特性を介して、水環境について広域的に調査を継続している。ここでは、調査分析が完了した 60 箇所

(表-5 の○印) の内、52 箇所の水質特性を表-2 にまとめている。湧水群となっている箇所では、紙面の関 係上、代表的な 1 箇所の結果を提示している。周知のことではあるが、湧水等の自然水の水質特性は、地質 環境と人為的要因によって大きく支配される。主要溶存イオン量に基づいて、へキサダイヤグラムとトリリ ニアダイヤグラムで表示した水質特性を図-6(a)と(b)及び図-7(a)と(b)にまとめている。溶存イオン量の高い 自然水は、都会域等の人為的活動の活発な地域に見られる場合が多く、これらの自然水は、硬水化が進んで おり直接飲料できないものがほとんどであった。また、関東域に点在する自然水はほとんど、アルカリ土類 炭酸塩とアルカリ土類非炭酸塩に分類される。特に、山間部や山岳域の自然水は、アルカリ土類炭酸塩に分 類されるものがほとんどであった。これらの自然水の調査を継続していて実感することは、数十年前までは 疑いもなく飲料水等の生活用水に利用・活用されていたが、そのまま飲料できる自然水が確実に山間部から 山岳域へと移行しつつあることであった。今後さらに調査の充実を計り、自然水の貴重性に警鐘を鳴らして いきたい。

表-2 関東域に散在する自然水の水質分析結果

\begin{tabular}{|c|c|c|c|c|c|c|c|c|c|c|c|c|c|c|c|c|c|}
\hline \multirow[t]{2}{*}{$\sqrt{N_{0}}$} & \multirow[t]{2}{*}{ 鍀所 } & \multirow[t]{2}{*}{ 名水名 } & \multirow[t]{2}{*}{ 採取年月日 } & \multirow[t]{2}{*}{ 水形息 } & \multirow[t]{2}{*}{$\overline{\mathrm{pH}}$} & \multirow{2}{*}{$\begin{array}{c}\mathrm{EC} \\
(\mu \mathrm{s} / \mathrm{cm})\end{array}$} & \multirow{2}{*}{$\begin{array}{c}T \\
(\mathrm{C})\end{array}$} & \multicolumn{4}{|c|}{ 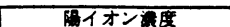 } & \multicolumn{4}{|c|}{ 度イオン註度 } & \multirow{2}{*}{$\begin{array}{l}\text { 全硕度 } \\
(\mathrm{mg} / \mathrm{l})\end{array}$} & \multirow{2}{*}{ 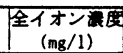 } \\
\hline & & & & & & & & $\mathrm{Na}$ & $\frac{1+1}{k}$ & $\mathrm{Ca}$ & $\overline{M g}$ & $\mathrm{HCO} 3$ & $\mathrm{Cl}$ & NO3 & S04 & & \\
\hline 1 & 家京部谷区 & 消正の井 & H.5.10.31. & 涌木 & 6.5 & & & 5.8 & 0.5 & 9.1 & 5.3 & $\frac{32.6}{32 .}$ & 12.0 & 12.7 & 3.7 & 44.6 & \\
\hline 2 & 策京的自区 & 自不办神水 & H.5.10.14. & 到水 & 6.8 & & & 21.5 & 0.8 & 15.0 & 10.5 & 61.0 & 22.8 & 29.7 & 21.3 & 80.5 & 182.56 \\
\hline 3 & 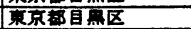 & 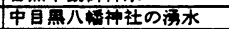 & H. 7.12.24. & 滥水 & 6.7 & 330 & 16.5 & \begin{tabular}{|l|}
27.6 \\
\end{tabular} & 0.9 & 16.9 & 10.5 & 45.4 & 28.5 & 45.8 & 30.6 & 85.0 & 205.93 \\
\hline 5 & 㕿京部世田谷区 & 每多罗不场の流 & H. 6.12 .9 & 杼木 & 6.7 & 230 & & 15.4 & 1.2 & 15.3 & 9.2 & 66.1 & 16.1 & 27.5 & 11.8 & 76.2 & 162.66 \\
\hline 6 & 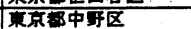 & 白部掼視水 & H. 5.10 .31 . & 标标 & 6.2 & & & 26.4 & 3.1 & 22.0 & 11.2 & 70.8 & 32.5 & 37.1 & 27.5 & 100.9 & 230.56 \\
\hline 7 & 佂京部濩区 & त井声 & H. 6.12 .9 & 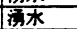 & 6.8 & 320 & & 16.8 & 6.9 & 28.9 & 7.4 & 93.0 & 16.5 & 17.3 & 32.9 & 102.4 & 219.60 \\
\hline 8 & 页京都品川区 & 大井の末楪 & H. 5.10 .31 . & $\frac{10}{3}$ & 6.6 & & & 20.1 & 4.6 & 40.9 & 9.9 & 129.3 & 20.0 & 17.6 & 42.3 & $\frac{02.7}{142.9}$ & 284.73 \\
\hline 9 & 帮京神台家区 & 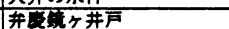 & H. 5.10.26. & 开声木 & 6.7 & & & $\frac{0.2}{16.6}$ & 9.1 & 56.3 & 14.3 & 186.8 & 19.3 & 18.7 & 49.7 & 199.4 & 370.71 \\
\hline 10 & 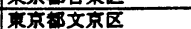 & 一菜の生佸并戸 & H. 5.11.7. & 宑示水 & 6.5 & & & 23.7 & 9.2 & 44.2 & 9.0 & 97.6 & 24.1 & 65.4 & 42.3 & 147.3 & 315.40 \\
\hline 12 & 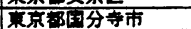 & 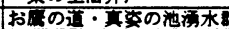 & H. 5.4.27. & 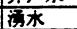 & $\frac{.04}{6.4}$ & & & 9.8 & 0.5 & 14.6 & 7.7 & 48.6 & 14.2 & 23.8 & 10.7 & 68.2 & 130.02 \\
\hline 13 & 变京好小会并帝 & 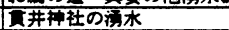 & H.5.11.7. & 洒水 & 6.1 & & & 12.2 & 0.8 & 18.9 & 8.7 & 66.2 & 15.0 & 29.6 & 10.8 & 83.0 & 162.16 \\
\hline 14 & 家京部三要市 & 重川公圆の滥水 & H. 6.5.1. & 泟水 & 8.2 & 195 & 16.2 & 13.7 & 2.5 & 14.7 & 7.2 & 63.5 & 14.4 & 20.7 & 9.9 & 66.2 & 146.65 \\
\hline 15 & 家京都田立市 & 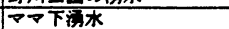 & H.7.6.20. & 满林 & 6.5 & 270 & 15.2 & 19.1 & 3.6 & 27.0 & 9.7 & 71.0 & 16.1 & 38.7 & 39.6 & 107.1 & 224.78 \\
\hline 21 & 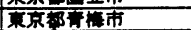 & 小滀暹の仕込み末 & H.7.4.8. & 沙标 & 7.7 & 220 & 17.6 & 7.8 & 1.9 & 30.7 & 5.6 & 95.6 & 9.1 & 2.2 & 25.1 & 99.8 & 177.92 \\
\hline 26 & 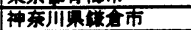 & 流并天の隻沅水 & H. 6.2.27. & 满水 & 7.8 & & & 13.7 & 1.4 & 40.4 & 6.9 & 128.2 & 25.3 & $\frac{.2}{2.7}$ & 17.1 & 129.3 & 235.72 \\
\hline$\frac{20}{27}$ & $\frac{1}{4}$ & 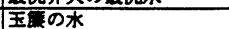 & H.8.11.7. & 滥水 & 7.5 & 102 & 16.0 & \begin{tabular}{|l|}
11.3 \\
\end{tabular} & $\frac{1.7}{1.7}$ & $\frac{3.2}{8.0}$ & 2.3 & 32.2 & \begin{tabular}{|l|}
17.3 \\
\end{tabular} & 2.2 & 3.2 & 29.2 & $\frac{20.12}{78.11}$ \\
\hline$\frac{21}{28}$ & 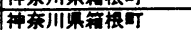 & 姲の木 & H.11.17. & 都标 & 7.7 & $\frac{56}{58}$ & $\frac{14.0}{14.0}$ & $\frac{4.4}{4.4}$ & 1.2 & 5.6 & 1.7 & 23.4 & 5.1 & $\frac{2.2}{3.6}$ & $\frac{0.2}{2.8}$ & 20.9 & $\frac{10.11}{47.80}$ \\
\hline 29 & 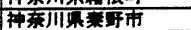 & 弘法の海水 & H.5.3.6. & 杼林 & 7.7 & & & 6.2 & 1.2 & 32.3 & 9.3 & 98.5 & 9.7 & 21.2 & 21.2 & 118.7 & 199.50 \\
\hline 30 & 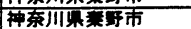 & 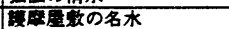 & H. 8.1.27. & 榎水 & 7.6 & 80 & 3.7 & 3.6 & 0.3 & 9.9 & 3.2 & 43.4 & 3.6 & 3.9 & 2.5 & 38.1 & 70.48 \\
\hline 31 & 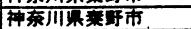 & 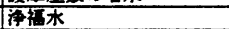 & H. 7.10 .10 & 标 & 7.4 & 179 & & 7.4 & 1.3 & 20.7 & 7.0 & 72.4 & 4.6 & 19.7 & 15.8 & 80.5 & 148.94 \\
\hline 32 & 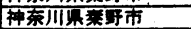 & 竜神の泉 & H. 7.10 .10 & 桶水 & 8.4 & 108 & & 3.3 & 0.6 & 13.0 & 3.6 & 47.8 & 3.2 & 5.5 & 6.8 & 47.3 & 83.76 \\
\hline$\frac{25}{33}$ & 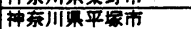 & 不老水 & H. 7.10 .10 & 格水 & 6.7 & 330 & & 17.1 & 1.8 & 44.5 & 19.0 & 82.0 & 26.6 & 79.4 & 57.8 & 189.3 & 328.30 \\
\hline$\frac{3}{34}$ & 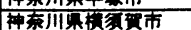 & 走水水原 & H. 8.9.16. & $\frac{1}{3}$ & $\frac{.1}{7.4}$ & $\frac{500}{280}$ & 18.0 & $\frac{11.2}{17.8}$ & 1.6 & $\frac{72.5}{24.2}$ & 11.8 & 75.0 & $\frac{20.0}{31.8}$ & $\frac{13.4}{13.4}$ & $\frac{31.0}{31.3}$ & $\frac{105.5}{108.9}$ & 206.87 \\
\hline$\frac{37}{35}$ & 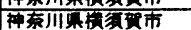 & 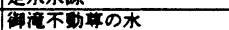 & H.8.11.3. & $\frac{103}{153}$ & 7.5 & $\frac{200}{440}$ & $\frac{20.0}{16.0}$ & $\frac{11.0}{15.4}$ & 3.5 & 82.2 & 7.7 & 207.5 & \begin{tabular}{|l|}
30.3 \\
\end{tabular} & 8.1 & \begin{tabular}{|l|}
53.1 \\
53
\end{tabular} & 237.2 & 407.86 \\
\hline 36 & 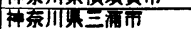 & 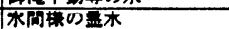 & H.5.5.9. & 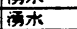 & 7.1 & & & $\frac{10.7}{13.0}$ & 2.2 & 25.6 & 8.2 & 91.6 & \begin{tabular}{|l}
23.8 \\
\end{tabular} & 16.4 & \begin{tabular}{|l}
6.6 \\
\end{tabular} & 97.6 & 187.23 \\
\hline 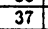 & 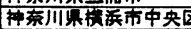 & 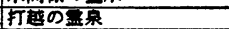 & H.7.12.7. & 枟木 & 6.6 & 330 & & 28.0 & 1.2 & 27.7 & 13.7 & 81.0 & 22.2 & 39.6 & 56.0 & 125.4 & 269.41 \\
\hline 38 & 种素川真山北开 & 茜木の泣 & H. 8.1.27. & 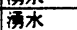 & 7.7 & 134 & 3.0 & $\frac{0.0}{5.6}$ & 0.5 & 19.3 & $\frac{1.1}{3.2}$ & 59.3 & $\frac{22.2}{5.0}$ & 6.7 & $\frac{0.6}{12.6}$ & $\frac{60.8}{61.5}$ & 112.22 \\
\hline 39 & 素川紧山北而 & ユーシン滛谷の澡水 & H. 8.1.27. & 篹流水 & 7.8 & 87 & 4.3 & $\frac{0.3}{4.3}$ & 1.5 & 12.5 & 1.7 & 40.4 & 3.4 & 2.5 & 9.1 & 38.1 & 75.31 \\
\hline 40 & 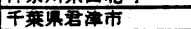 & 久而里の生きた木 & H. 7.12 .23 & 并正水 & 8.5 & 276 & 12.9 & 7.3 & 8.3 & 32.0 & 9.9 & 145.9 & 6.5 & 3.0 & 15.2 & 120.5 & 228.03 \\
\hline 41 & 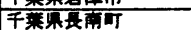 & 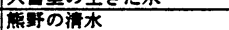 & H. 7.12 .23 . & 涪水 & $\frac{0.0}{8.6}$ & $\frac{204}{204}$ & $\frac{12.5}{13.7}$ & $\frac{1.3}{9.9}$ & $\frac{0.5}{3.0}$ & 24.2 & 5.7 & $\frac{89.3}{89.3}$ & 9.5 & $\frac{.0}{7.4}$ & $\frac{10.2}{16.0}$ & $\frac{83.8}{83.8}$ & $\frac{22.00}{165.08}$ \\
\hline 42 & 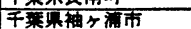 & 百自木公圆の井戸 & 2.23. & 涪水 & 8.7 & $\frac{207}{243}$ & $\frac{10.7}{14.4}$ & 11.5 & $\frac{0.0}{7.6}$ & 26.6 & 8.4 & 135.9 & 6.7 & - & \begin{tabular}{|l|l|}
13.8 \\
\end{tabular} & 100.7 & 210.37 \\
\hline 43 & 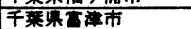 & 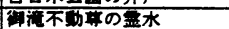 & H. 7.12 .30 & 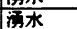 & 8.3 & $\frac{270}{269}$ & $\frac{1.7}{15.7}$ & 14.8 & 2.7 & 35.6 & 4.7 & 158.7 & 4.5 & 1.0 & 6.2 & 108.3 & 228.27 \\
\hline 47 & 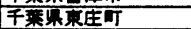 & 甾水大郚 & H. 8.4.28. & 标 & 7.2 & 450 & 16.2 & 31.4 & 3.5 & 25.6 & 21.3 & 2.1 & 50.2 & 133.1 & 42.6 & 151.1 & 309.73 \\
\hline 49 & 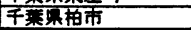 & 名戸ヶ谷䍇水任か & H. 7.11.19. & 桶水 & 7.4 & $\frac{305}{185}$ & 17.0 & 12.7 & 1.1 & 13.6 & 7.4 & 55.7 & 16.1 & 14.6 & \begin{tabular}{|l|}
2.7 \\
12.7
\end{tabular} & 64.4 & 133.90 \\
\hline 53 & 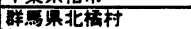 & 汿王 & H.9.7.3. & $\frac{10 \pi}{5}$ & 6.8 & $\frac{200}{210}$ & & 9.4 & 1.6 & 22.1 & 6.1 & 55.5 & 10.4 & 43.9 & \begin{tabular}{|l|}
6.8 \\
\end{tabular} & 80.2 & 155.87 \\
\hline 54 & 群鳥息宫城村 & 赤城神社二神水 & H.9.7.3. & $\frac{1}{5}$ & $\frac{.0}{6.9}$ & 54 & & $\frac{3.7}{2.7}$ & 0.6 & 6.7 & 0.6 & 24.0 & 2.3 & 2.0 & 1.4 & 19.3 & 40.33 \\
\hline 55 & 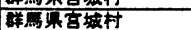 & 馬の木 & $\frac{10.7 .3}{4.9 .7 .3}$ & 助小 & $\frac{.9}{7.1}$ & $\frac{-1}{56}$ & & $\frac{2.1}{2.9}$ & 0.0 & $\frac{0.1}{7.1}$ & $\frac{0.0}{0.7}$ & $\frac{2.04}{28.4}$ & $\frac{2.5}{2.1}$ & $\frac{2.0}{0.5}$ & $\frac{1.8}{0.8}$ & 20.5 & $\frac{73.05}{43.23}$ \\
\hline 56 & 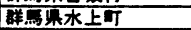 & 谷川岳PAの大海水 & H.8.6.2. & 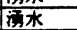 & 7.1 & 73 & 12.0 & 4.3 & 0.8 & 7.8 & $\frac{0}{1.2}$ & 27.4 & 3.2 & 0.9 & 6.8 & 24.4 & 52.39 \\
\hline 59 & 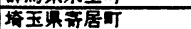 & 昌本本 & H.7.9.24. & $\frac{1}{15 \pi}$ & 7.2 & $\frac{174}{174}$ & $\frac{12.0}{11.9}$ & $\frac{7.0}{1.6}$ & 0.3 & 14.6 & 22.7 & 141.1 & $\frac{0.2}{4.4}$ & $\frac{2.5}{2.9}$ & 9.1 & 129.7 & 196.63 \\
\hline 62 & 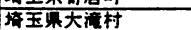 & 泆父港流 & H.7.11.4. & $\frac{10 \pi}{3}$ & 7.2 & $\frac{117}{88}$ & $\frac{1.5}{7.0}$ & $\frac{1.04}{3.4}$ & 0.2 & $\frac{17.0}{12.2}$ & 0.7 & 36.6 & $\frac{7.7}{1.4}$ & $\frac{2.3}{1.3}$ & $\frac{3.2}{7.5}$ & $\frac{25.1}{33.1}$ & 63.04 \\
\hline 63 & 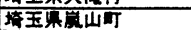 & 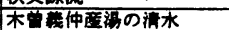 & H. 8.3.20. & 极 & 6.4 & 231 & 9.0 & $\frac{0.7}{9.3}$ & 3.2 & 21.4 & 12.1 & 7.6 & 44.9 & 29.5 & $\begin{array}{l}32.8 \\
\end{array}$ & 102.9 & 160.63 \\
\hline 65 & 城果大子相 & 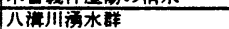 & H. 8.10 .26 & 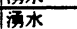 & 5.7 & $\frac{25}{32}$ & & 3.5 & 0.4 & 2.2 & 0.7 & 6.5 & 4.0 & 5.3 & 1.4 & 8.6 & 24.16 \\
\hline 77 & 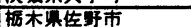 & 西洨原开天济演水 & H.9.4.10. & 标 & 7.3 & 280 & & 10.6 & 1.2 & 34.7 & 8.2 & 94.0 & 20.5 & 8.4 & 31.1 & 120.5 & 208.75 \\
\hline & 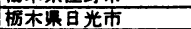 & 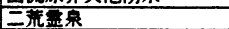 & H.7.5.5. & 标水 & 7.6 & 98 & & 7.1 & 1.9 & 8.7 & 1.9 & 42.2 & 5.7 & - & 4.4 & 29.4 & 71.84 \\
\hline 80 & 山梨果忽重村 & 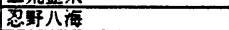 & H. 5.5.26. & 杼水 & 7.2 & 104 & & 4.8 & 1.3 & 10.6 & 4.1 & 60.0 & 2.5 & 0.3 & 1.9 & 43.0 & 85.53 \\
\hline 81 & 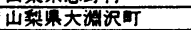 & 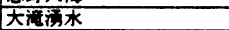 & H. 9.9.27. & 汿水 & 7.9 & 62 & 11.0 & 4.6 & 1.4 & 5.9 & 1.4 & 31.5 & 2.3 & 1.5 & 1.7 & 20.4 & 50.31 \\
\hline 83 & 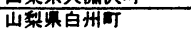 & 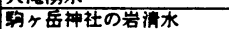 & H.9.9.27. & 洨水 & 8.7 & 58 & 11.0 & 3.1 & 1.8 & 7.1 & 0.8 & 32.5 & 0.7 & 0.5 & 2.0 & 21.1 & 48.48 \\
\hline 87 & 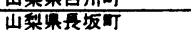 & 女取汿木 & H.9.9.27. & 标水 & $\frac{.19}{7.9}$ & $\frac{30}{46}$ & 8.5 & $\frac{3.1}{3.4}$ & $\frac{1.0}{1.4}$ & $\frac{1.1}{4.8}$ & $\frac{0.0}{1.0}$ & $\frac{28.3}{28.3}$ & 0.18 & $\frac{.0}{-}$ & $\frac{2.0}{1.0}$ & $\frac{1.1}{16.2}$ & $\frac{70.70}{40.65}$ \\
\hline 88 & 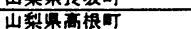 & 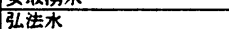 & H.9.9.27. & 标水 & 7.6 & 87 & $\frac{0.0}{10.5}$ & $\frac{0.7}{4.5}$ & $\frac{1.3}{1.5}$ & 8.4 & 2.3 & $\frac{3.0}{38.4}$ & $\frac{0.0}{3.3}$ & 6.0 & $\frac{1.0}{0.9}$ & 30.3 & $\frac{2.03}{65.24}$ \\
\hline 89 & 山整果是䛀打 & 三分一酒水 & H. 9.9 .27 . & 水 & 8.1 & $\frac{11}{62}$ & 9.5 & 3.7 & 1.5 & 6.5 & 1.6 & 36.5 & $\frac{0.0}{1.0}$ & 0.9 & 0.8 & 22.9 & 52.54 \\
\hline 90 & 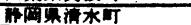 & 柿田川湤水羘 & H. 5.5.23 & 泟水 & 7.2 & 137 & & $\frac{.0}{7.2}$ & $\frac{1.0}{1.5}$ & 13.0 & 5.0 & 59.2 & 5.1 & 2.7 & 13.7 & 54.5 & 108.07 \\
\hline 94 & 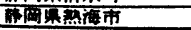 & 鶖海のおいしい木 & H. 8.8.10 & 汿木 & 7.5 & 162 & 18.8 & $\frac{.2}{9.9}$ & 2.3 & 14.6 & 4.8 & 64.7 & 9.8 & -4 & 13.2 & 56.2 & 119.21 \\
\hline
\end{tabular}



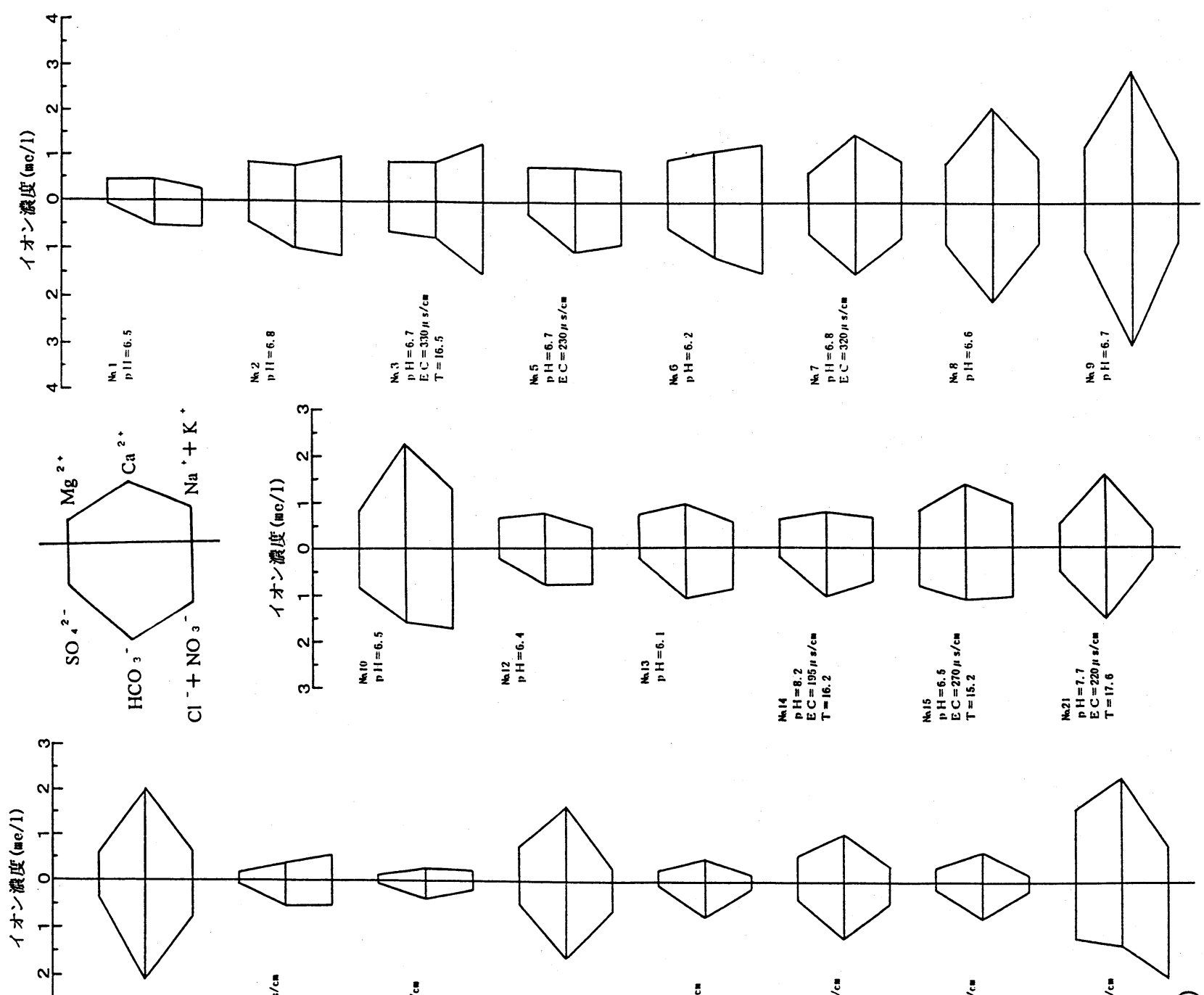

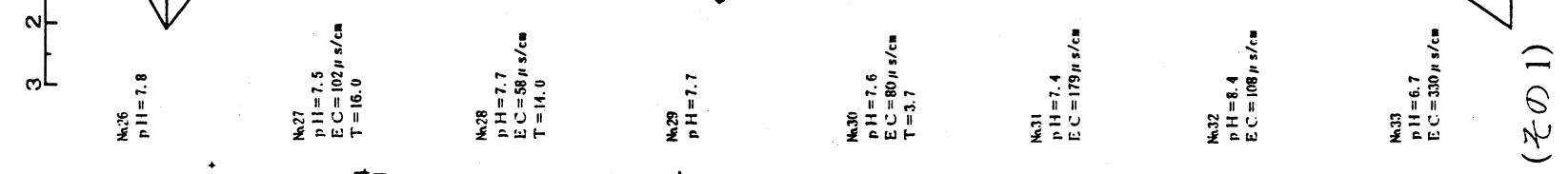
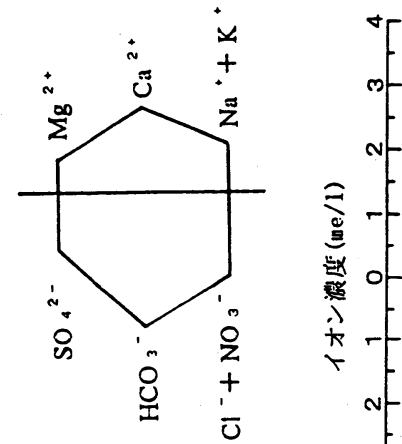

of of की

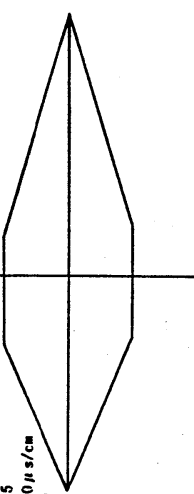



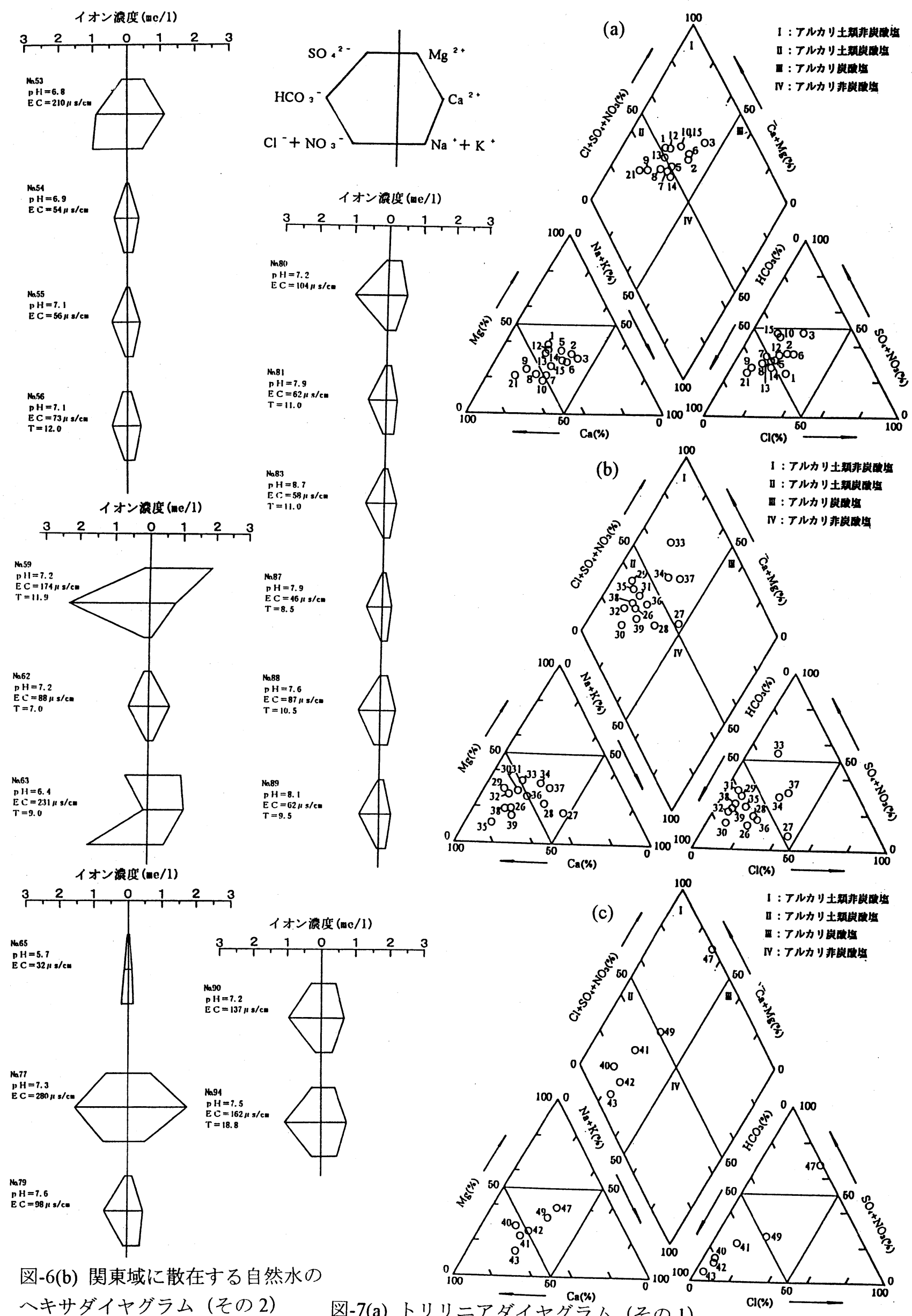

図-6(b) 関東域に散在する自然水の

ヘキサダイヤグラム (その 2)

図-7(a) トリリニアダイヤグラム (その 1) 


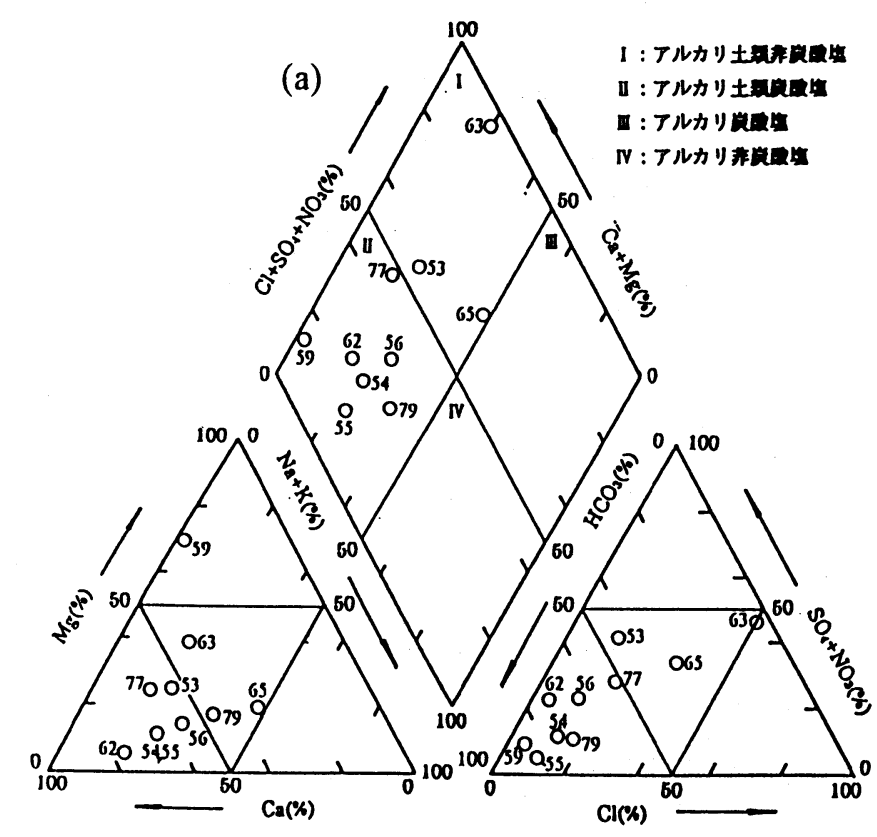

図-7(b) トリリニアダイヤグラム (その 2)

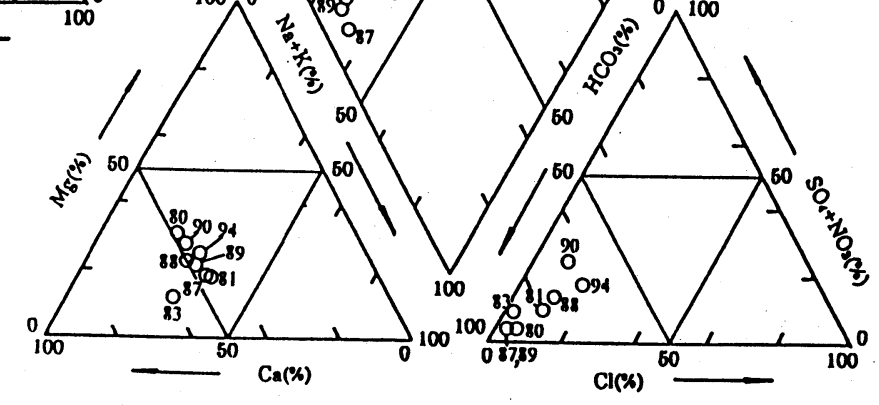

\section{6. 結びにかえて}

信濃川（千曲川）源流の正体とその流域における水質特性等について提示した。また関東域に点在する 名水と呼ばれている自然水の水環境の実態に関する調査成果の一部について概説した。源流域で育まれる天 の恵み、「生命の水」も、直接飲料できる自然水は、平野部から山間部・山岳部へと確実に移行しつつある ことに強く印象を受けた。現在、全国的に我が国の主要大河川の源流域の水環境の実態調查を継続している。 また、故事来歴のある環境庁指定名水百選を中心に、全国的に湧水や井戸水等の自然水の硝酸性窒素污染状 況等の分析・評価を試みている。一日も早く調査地点の充実と科学的データの蓄積を計り、日本列島自然水 環境マップの完成を急ぎたいと思っている。特に、学会や学術レベルの成果で留まることなく、地域住民へ の還元や協力・理解八の実践的活動を計り、水環境の保全・回復の重要性に警鐘を鳴らしていきたいと切望 する。

\section{参考文献}

1）山口晴幸ら（1995）：世界自然遺産「屋久島」からの自然環境レポート、地盤工学会誌、土と基礎、Vol.43、 No.6、pp.53 57.

2）山口晴幸ら（1996）: 古都鎌倉の水と土、地艋工学会誌、土と基礎、Vol.44、No.4、pp.45 48.

3）山口晴幸ら（1996）: 生命の水・多摩川源流一東京湧水天国一、土木学会第 4 回地球環境シンポジウム講 演集、pp.259 270).

4）山口晴幸ら（1997）: 生命の水・多摩川源流、地盤工学会誌、土と基礎、Vol.45、No.4、pp.34 37.

5) 山口晴幸ら (1997) : 生命の水・利根川源流・流域の自然環境、土木学会第 5 回地球環境シンポジウム講 演集、pp.187 196. 